Article

\title{
Experimental Analysis of Modified DC-P\&O Technique with Arm Controller for a Stand-Alone 40 W PV System
}

\author{
Ashish Kumar Singhal ${ }^{1}$, Narendra Singh Beniwal ${ }^{2}$, Khalid Almutairi ${ }^{3, *(\mathbb{D}, \text { Joshuva Arockia Dhanraj }}{ }^{4,5}(\mathbb{D}$, \\ Ali Mostafaeipour ${ }^{5,6}$, Alibek Issakhov ${ }^{7,8}$, Prem Kumar Chaurasiya ${ }^{9}$, Hossein Goudarzi 10 \\ and Vinod Kumar Singh ${ }^{11} \mathbb{D}$
}

1 Electrical Engineering Department, Dr. A.P.J. Abdul Kalam Technical University, Lucknow 226031, Uttar Pradesh, India; ashishee@gmail.com

2 Electronics Engineering Department, Bundelkhand Institute of Engineering and Technology, Jhansi 284128, Uttar Pradesh, India; narendra.beniwal@gmail.com

3 Mechanical Engineering Technology, Applied College, University of Hafr Al Batin, Hafar Al Batin 39524, Saudi Arabia

4 Centre for Automation and Robotics (ANRO), Department of Mechanical Engineering, Hindustan Institute of Technology and Science, Padur, Chennai 603103, Tamil Nadu, India; joshuva1991@gmail.com

5 Environmental Assessment and Technology for Hazardous Waste Management Research Center, Faculty of Environmental Management, Prince of Songkla University, Hat Yai, Songkhla 90110, Thailand; mostafaei@yazd.ac.ir

6 Industrial Engineering Department, Yazd University, Yazd 8915818411, Iran

7 Department of Mathematical and Computer Modelling, Faculty of Mechanics and Mathematics, Al-Farabi Kazakh National University, Almaty 050040, Kazakhstan; alibek.issakhov@kaznu.kz

check for updates

Citation: Singhal, A.K.; Beniwal, N.S.; Almutairi, K.; Arockia Dhanraj, J.; Mostafaeipour, A.; Issakhov, A.; Chaurasiya, P.K.; Goudarzi, H.; Singh, V.K. Experimental Analysis of Modified DC-P\&O Technique with Arm Controller for a Stand-Alone 40 W PV System. Energies 2021, 14, 6169. https://doi.org/10.3390/en14196169

Academic Editor: José Matas

Received: 10 August 2021

Accepted: 26 August 2021

Published: 27 September 2021

Publisher's Note: MDPI stays neutral with regard to jurisdictional claims in published maps and institutional affiliations.

Copyright: (c) 2021 by the authors. Licensee MDPI, Basel, Switzerland. This article is an open access article distributed under the terms and conditions of the Creative Commons Attribution (CC BY) license (https:// creativecommons.org/licenses/by/ $4.0 /)$.
8 Department of Mathematics and Cybernetics, Kazakh British Technical University, Almaty 050000, Kazakhstan

9 Faculty of Mechanical Engineering Department, Sagar Institute of Science and Technology, Gandhi Nagar, Bhopal 462036, Madhya Pradesh, India; prem.chaurasiyaa@gmail.com

10 School of Architecture and Planning, University of New Mexico, Albuquerque, NM 87131, USA; goodarzi.ho@gmail.com

11 Electrical Engineering Department, SRGI, Jhansi 284002, Uttar Pradesh, India; singhvinod34@gmail.com

* Correspondence: khalid.almutairi@uhb.edu.sa

Abstract: The world is moving towards the generation of electricity with renewable energy sources (RES) due to the deterioration of the green environment and trying to replace non-renewable energy resources. The real-time results are achieved with the help of an arm controller, having good controller efficiency with the Waijung toolbox, compatible with MATLAB using STM32ST-link utility. In this paper, the authors are focused on areas such as easy to implement controller efficiency, and real-time solutions for modified direct-control perturbation \& observation (DC-P\&O) technique based on 32- bit ARM Cortex microcontroller (STM32F407VGT6) with embedded programming using Waijung blocksets, which offers very expected outcomes of the problem to make the stand-alone system efficient with fast-tracking. The observation setup is tested with a 40-watt photovoltaic (PV) panel with resistive load for achieving its stability. The designed algorithm enhances the efficiency of the controller by $84.48 \%$ for the real-time parameters of the PV panel at maximum power point (MPP) for a $57 \%$ duty ratio.

Keywords: maximum power point technique (MPPT); modified (DC-P\&O); 32- bit arm microcontroller; MATLAB Simulink; PSIM1

\section{Introduction}

The global climate and energy crisis is demanding more renewable electricity to be generated by solar cells and also poses a major concern for the present civilized world. The limited reservoirs of conventional fuels and emission of greenhouse gases are greatly responsible. Moreover, it was reported that still today $86 \%$ of the world's energy consumption is met by conventional fuels and it is increasing daily [1]. 
To overcome this concern, renewable energy sources (RES) play a vital role in producing power across the world throughout the year with a green concept [2].

\subsection{Background, Motivation, and Related Work}

J. Prasanth Ram et al. [3] have proposed an MPPT survey on different MPP algorithms and their critical analysis has been performed concerning areas like speed tracking, the complexity of the algorithm, difficulties in hardware implementation. Jen-Hao Teng et al. [4] presented that MPPT is very important to extract maximum power in realtime. The challenges of MPPT are the step size of control variables and the high cost of hardware implementation. This paper proposes an estimation of the MPPT parameter. Mahmoudian et al. [5] found a maximum output power, using MPPT. In this paper, an artificial intelligence (AI) based technique is suggested and others are proposed based on their performance and effectiveness compared to other MPPT techniques. Singh et al. [6] presented MPPT as useful for PV systems to get the maximum output power with the beta technique based on the merits of steady-state performance and their fast-tracking speed. New hybrid MPPT techniques were used with the help of adaptive scaling factor (ASF) and P\&O. Dallago et al. [7] presented a D-MPPT based on identifying MPP. Hardware results were performed on the breadboard. The tracking efficiency is claimed to be $78.8 \%$ of the DC-P\&O method. Francisco et al. [8] considered P\&O methods are widely used because of their simplicity. The $\mathrm{P} \& \mathrm{O}$ has limitations for steady-state operation. Hegazy et al. [9] presented different MPPT techniques for boost converters and was simulated using PSIM and MATLAB software. The objective of this paper is to simulate different MPPT techniques to check their performance. In the conclusion, FLC techniques are proposed for reduction with a lower percentage for different duty cycles.

Dengsheng et al. [10] discussed the importance of the MPPT controller as suggested and also gave the direction to design it. Ehssein et al. [11] gave ideas for different topologies of a dc-dc convertor with their optimal controller using various techniques. Valenciaga et al. [12] introduced the novel technique of MPPT based on a second order sliding mode gradient server for a partial shading system. Rekioua et al. [13] worked on various MPPT methods for hybrid RES for a stand-alone system.

\subsection{Research Gap}

The literature suggests that solar technology is performing with flying colors across all green sources (GS). Solar technology consists of many solar cells combined in series and in parallel for producing large voltage and current, respectively. The authors have discussed the various energy sources available. The Sun itself is a massive fusion reactor in which hydrogen atoms are fused into helium. The energy from this fusion reaction is released into space in the form of radiation. The authors have already calculated the value of the radiation power of the sun $(3.828 \times 1026 \mathrm{~W})$, which we used to calculate the solar constant $\left(1367 \mathrm{~W} / \mathrm{m}^{2}\right)$. We totalled the energy according to the AM1.5 spectrum in Figure 1 and found $835 \mathrm{~W} / \mathrm{m}^{2}$ was received. Thus $61 \%$ of the originally available $1367 \mathrm{~W} / \mathrm{m}^{2}$ is received on earth as direct radiation [14]. However, it is important to pay attention to a large portion of radiation, namely the diffused radiation caused by the scattering of the light in the atmosphere for the given spectrum, where global radiation $(G)$ is a summation of direct and diffuse radiation. Therefore, the authors used $1000 \mathrm{~W} / \mathrm{m}^{2}$ as the total irradiance for peak power of a solar module [15].

In this study, the solar cell schematic is presented in Figure 2 with the DC load (resistive) and whose I-V characteristic is obtained when the load is varied with a different value of current and voltage is measured [16,17]. 


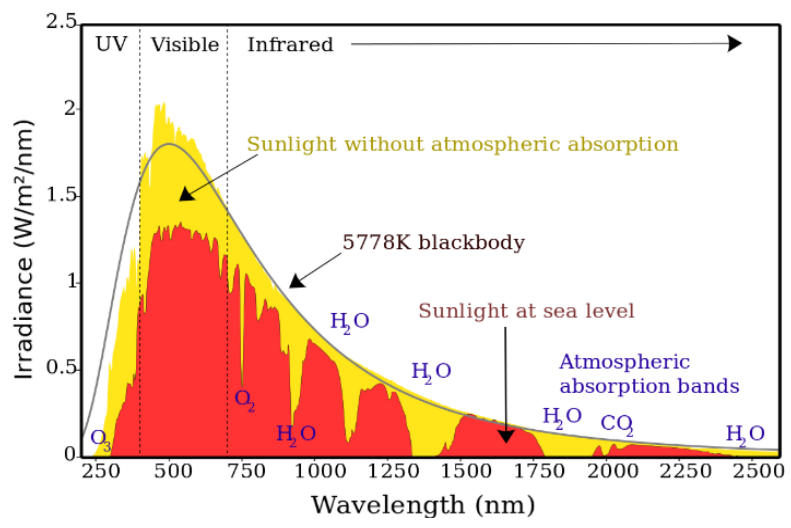

Figure 1. Real-time direct light solar radiation spectrum for atmosphere and sea level.

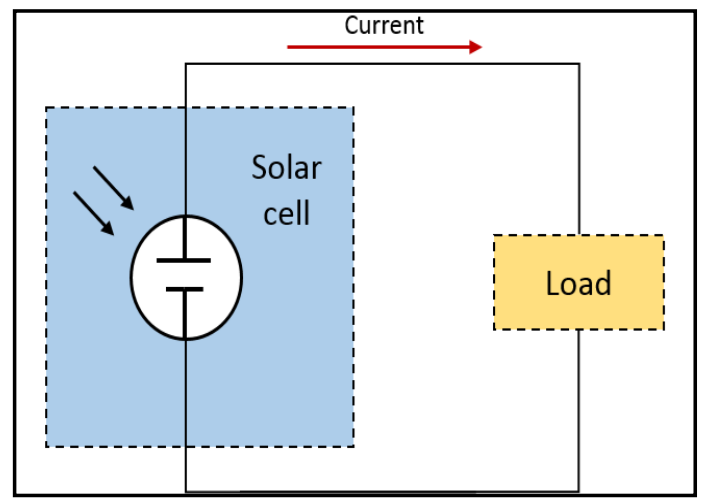

Figure 2. Ideal circuit of PV model.

To amend the efficiency of solar cells, many maximum power point techniques (MPPT) have been proposed in the literature, e.g., perturb and observe (P\&O) or hill-climbing, improved perturb and observe (IP\&O), incremental conductance (IC) technique, open circuit voltage methods, a fuzzy logic technique, DC-P\&O, short circuit current and suggested modified $\mathrm{P} \& \mathrm{O}$ technique with some changes in the parameter for less steady-state oscillation and fast-tracking [18].

\subsection{Contribution and Case Description}

- This work is carried out with a modified and fast-tracking DC-P\&O technique, which helps to fix the MPP at a certain point.

- The observation setup is tested with a $40 \mathrm{~W}$ PV panel with a dc load for charging from the PV panel.

- Designed algorithm for controller gives better efficiency of PV panel when comparing the result with PWM charge controller.

- Modified DC-P\&O technique used to improvise in the conventional P\&O by using direct controlling with the help of proportional integral derivative (PID) controller by $84.48 \%$.

This case is focused on the solution to the problem of solar cells with practical implementation. In the literature, some researchers are facing a problem in solar cells due to their high cost and inclination for low conversion efficiency. The authors are trying to focus the attention of the researcher with a feasible solution. The case is related to the design MPPT charge controller with modified DC-P\&O method using an efficient DC-DC boost convertor and an intelligent, efficient and low-cost 32- bit ARM Cortex microcontroller (STM32F407VGT6) with $168 \mathrm{MHz}$ frequency testing for optimal results with a $40 \mathrm{~W}$ panel having DC load [19]. 


\section{Materials and Methods}

In this paper, the authors attempt to help all learners understand the overall workflow with the help of the block diagram given below in Figure 3. The methodology of the workflow is discussed step by step.

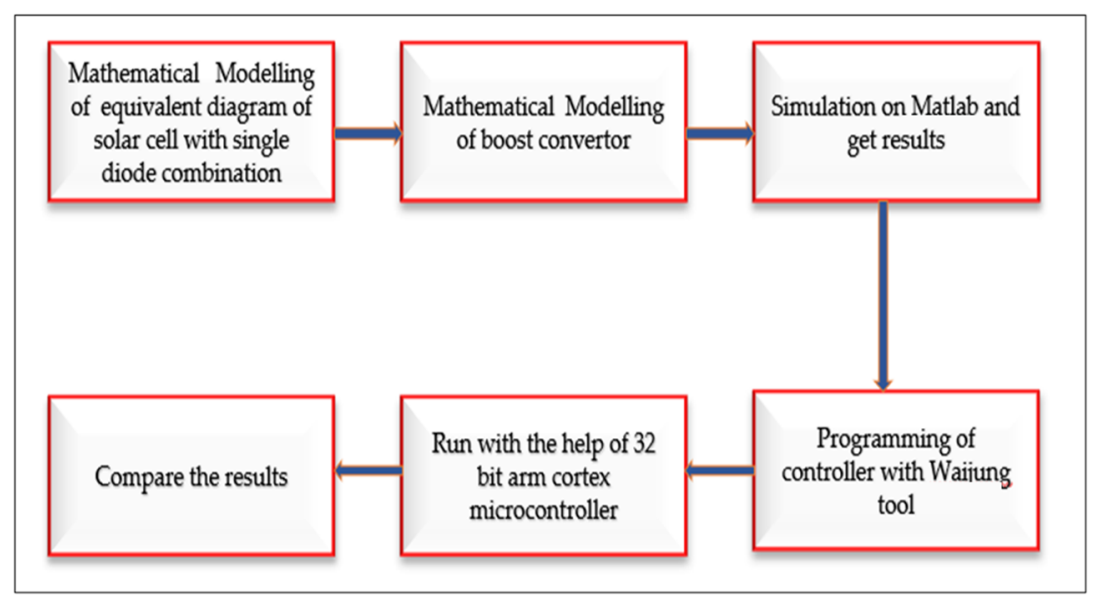

Figure 3. Block diagram of the workflow.

\subsection{PV Technology}

Despite the advantages of PV technology like clean, pollution-free, and non-exhaustible etc., solar cells are facing challenges due to their nonlinear characteristic, which lies in the irradiance and ambient temperature, and very low efficiency due to partial shading. In a stand-alone solar system, PV modules and batteries are pricier and directly coupled with PV modules, protecting against changing over [20].

Charge controllers play a very vital role as a solution to bring through the batteries from changing over. But charge controllers cannot operate PV modules at MPP, due to lower efficiency. To overcome this issue, the researcher needs to operate the PV module at the peak power point to deliver maximum power from the source to load under variable atmospheric conditions [21].

\subsection{Single Diode Equivalent Circuit of PV Cell with their Simulation}

Nowadays, PV has become popular for many applications such as lighting, battery charging, wireless power transmission, water pumping for agriculture, and satellite power systems. The single diode model is based on five important parameters discussed in Figure 4 . The photon current $\left(\mathrm{I}_{\mathrm{ph}}\right)$ is generated by incident light (insolation) on the solar cell. The diode is connected for safety purpose due to any damage and disturbance in PV module. The shunt and series resistance are passive elements to represent the power losses. The single diode model is shown in Figure 4.

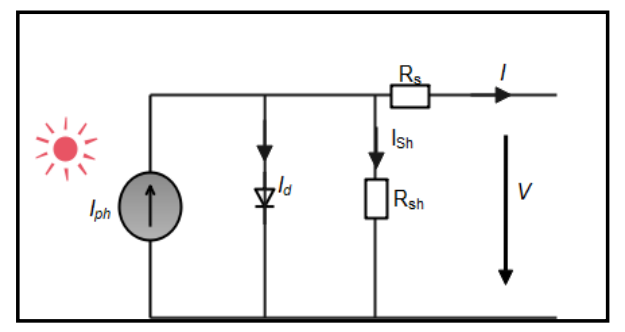

Figure 4. Single diode equivalent circuit of PV cell.

The model has experimented and simulated a PV panel (Waree solar 40 Watt) with different parameters specified in Table 1 on MATLAB software with different irradiance 
and temperature [21,22]. The output current can be measured from Figure 4, By applying $\mathrm{KCL}$, we can obtain:

$$
I=I_{p h}-I_{D}-I_{s h}
$$

where, $I_{p h}$ : Photon current $(\mathrm{A}), I_{D}$ : diode current $(\mathrm{A}), I_{\text {sh }}=$ shunt current $(\mathrm{A}), I$ : load current (A).

Table 1. Solar panel specification at $1000 \mathrm{~W} / \mathrm{M}^{2}$ and cell temperature $25^{\circ} \mathrm{C}$.

\begin{tabular}{ccc}
\hline S.No & Name of the Parameter & Values \\
\hline 1 & Maximum Power & $40 \mathrm{~W}$ (Waree solar) \\
2 & Open Circuit Voltage Voc & $21.4 \mathrm{~V}$ \\
3 & Short Circuit Current Isc & $2.65 \mathrm{~A}$ \\
4 & Maximum Power Current Imp & $2.10 \mathrm{~A}$ \\
5 & Maximum Voltage Vmp & $17.7 \mathrm{~V}$ \\
6 & No. of Cell in series & 36 \\
7 & Type & Monocrystalline Panel \\
8 & Frame Type & Aluminum \\
9 & Weight & $4.10 \mathrm{Kg}$ \\
\hline
\end{tabular}

The diode current equation can be represented as follows:

$$
I_{D}=I_{0}\left[\exp \left(\frac{V+I R_{s}}{m V_{T}}\right)-1\right]
$$

where $I_{0}$ : reverse saturation current $(\mathrm{A}), V$ : load voltage $(\mathrm{V}), R_{s}$ : series resistance (ohm), $m$ : diode ideality factor (unitless), $k$ : Boltzmann's constant $\left(1.381 \times 10^{-23} \mathrm{~J} / \mathrm{K}\right)$.

$$
I_{s h}=\left(\frac{V+I R_{s}}{R_{s h}}\right)
$$

where, $R_{s h}$ : shunt resistance (ohm).

$$
I=I_{p h}-I_{0}\left\{\exp \left[\frac{q\left(V+I R_{s}\right)}{m k T}\right]-1\right\}-\frac{V+I R_{s}}{R_{s h}}
$$

where, q: charge $\left(1.6 \times 10^{-19} \mathrm{C}\right) \mathrm{T}$ : absolute temperature $\left(V_{T}=\frac{k T}{q} \approx 0.0259 \mathrm{~V}\right)$ at $25{ }^{\circ} \mathrm{C}$.

Simulation carried with different levels of irradiance $2,704,806,008,001,000 \mathrm{~W} / \mathrm{M}^{2}$ at cell temperature $25^{\circ} \mathrm{C}$. Modeling of stand-alone PV obtains various results as shown in Figures 5-7.

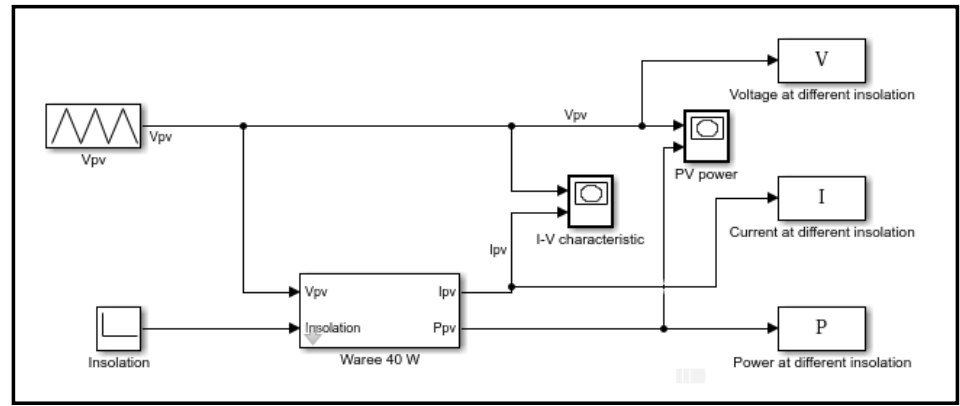

Figure 5. Simulation of Waree solar panel 40 watt. 


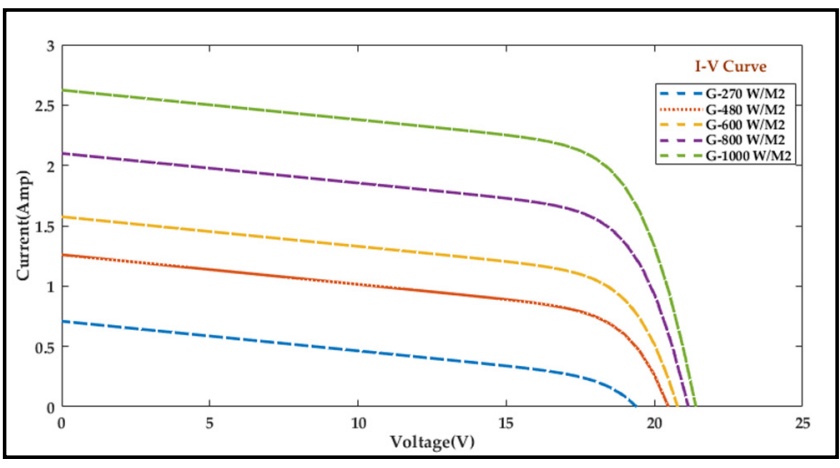

Figure 6. I-V curve of PV panel.

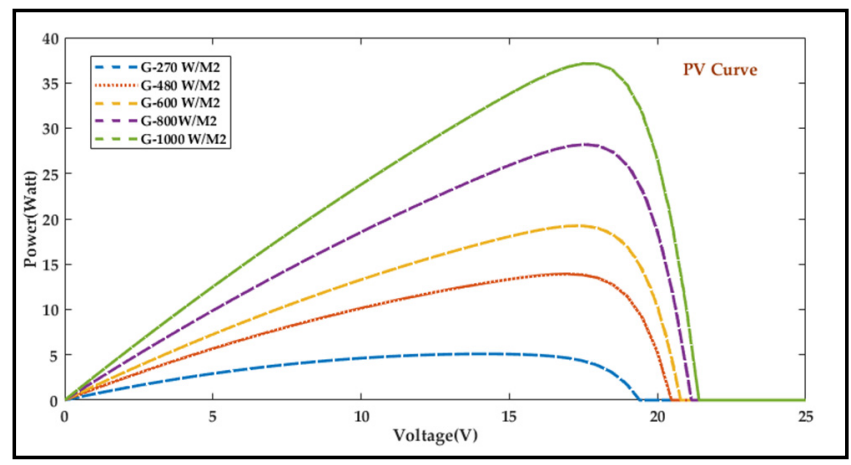

Figure 7. P-V curve of PV panel.

After getting the result of irradiance at $800 \mathrm{~W} / \mathrm{M}^{2}$, we found the $V o c=17.5$ volt, Isc $=2.15 \mathrm{amp}, \mathrm{Vmp}=17.5$ volt, $\mathrm{Imp}=1.75 \mathrm{amp}$ as shown in Figure 7.

Table 1, as shown below, represents the parameters of the PV panel used for the experimental bench. These parameters are useful for getting the optimal results as well as to find the efficiency of the solar cell. Panel efficiency can be calculated by [23].

$$
\begin{gathered}
\eta=\frac{P_{\max }}{P_{\text {in }}} \\
\% \eta=\frac{V_{o c} \times I_{S C} \times F F}{P_{\text {in }}} \times 100 \\
\% \eta=\frac{21.4 \times 2.65 \times 0.78}{343} \times 100 \\
\% \eta=12.8 \%
\end{gathered}
$$

\section{The Functioning of DC-DC Boost Converter}

A DC-DC boost converter shown in Figure 8a, was used to step up the voltage level where the input end was low. It consisted of an inductor, output capacitor, and switching device. There were two modes of operation depending upon the switching shown in Figure 8b,c [24]. Switching can be achieved by either a metal-oxide field-effect transistor (MOSFET) or an insulated gate bipolar transistor (IGBT). For low voltage, MOSFET is preferred rather than high voltage applications. IGBT is preferred due to its high input impedance and high voltage rating application greater than $1 \mathrm{kV}$. The output voltage can be regulated by switching devices with the variation of the duty cycle [25]. It can be represented as follows:

$$
\frac{V_{o}}{V_{i}}=\frac{t_{s}}{t_{o f f}}=\frac{1}{1-D}
$$




$$
t_{o n}+t_{o f f}=t_{s}
$$

where, $V_{o}=$ output voltage; $V_{i}=$ input voltage; $t_{\text {off }}=$ IGBT off, sec; $t_{o n}=$ IGBT on, sec; $t_{s}=$ total time.

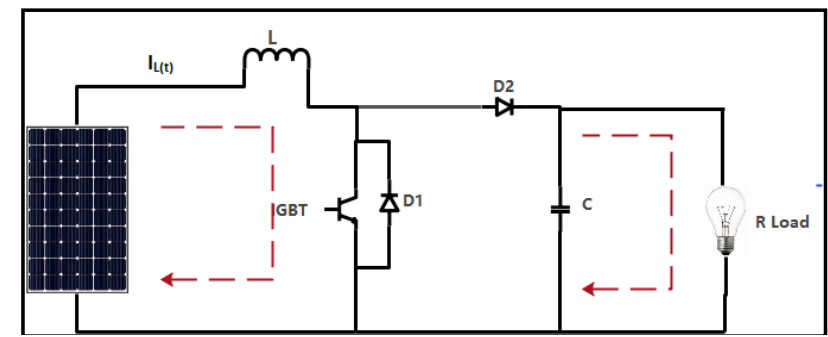

(a)

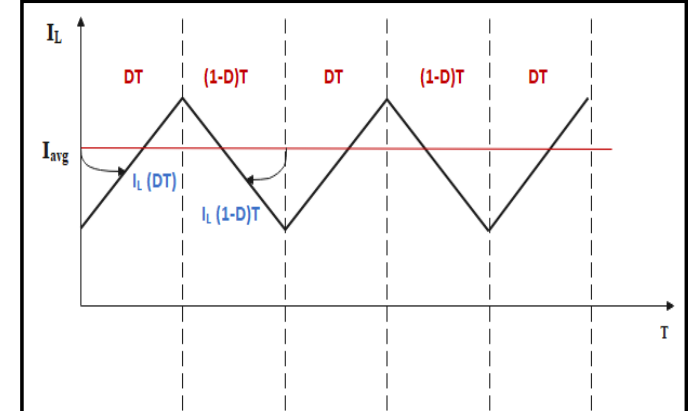

(b)

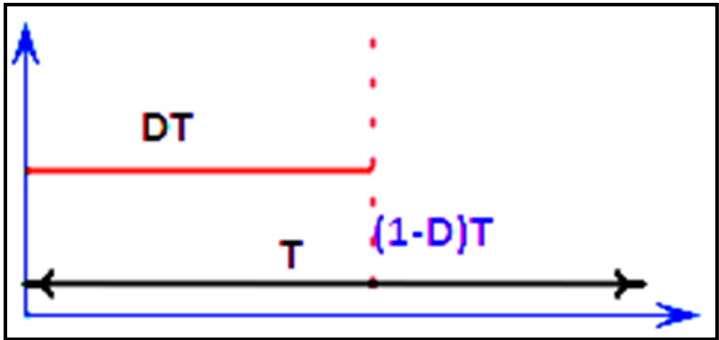

(c)

Figure 8. Circuit diagram, waveform and duty cycle of DC-DC boost convertor (conduction state) (a) circuit diagram; (b) the waveform of DC-DC boost convertor with their average; (c) duty cycle.

When the switch is ON, the diode will develop reverse bias then the state-space equation can be written as follows:

$$
\left[\begin{array}{c}
i_{l}^{\bullet} \\
v_{c}^{\bullet}
\end{array}\right]=\left[\begin{array}{cc}
0 & 0 \\
0 & -\frac{1}{R C}
\end{array}\right]\left[\begin{array}{c}
i_{l} \\
v_{c}
\end{array}\right]+\left[\begin{array}{c}
\frac{1}{L} \\
0
\end{array}\right]\left[v_{g}\right]+\left[\begin{array}{c}
0 \\
-\frac{1}{C}
\end{array}\right]\left[i_{c}\right]
$$

When the switch is OFF, the diode will develop forward bias then the state-space equation can be written as follows:

$$
\left.\begin{array}{c}
(1-d) T_{s}:- \\
i_{l}^{\bullet} \\
v^{\bullet}
\end{array}\right]=\left[\begin{array}{cc}
0 & -1 / \mathrm{L} \\
1 / c & -1 / R C
\end{array}\right]\left[\begin{array}{c}
i_{l} \\
v_{c}
\end{array}\right]+\left[\begin{array}{c}
y_{l} \\
0
\end{array}\right] v_{g}+\left[\begin{array}{c}
0 \\
-1 / \mathrm{LC}
\end{array}\right]\left[i_{c}\right]
$$

The required minimum value of the inductor can be written in continuous conduction mode (CCM) as follows:

$$
L=\frac{V_{o}(1-D)}{2 I_{o} f_{P W M}}
$$


After consideration of the output voltage ripple, the capacitor value can be written as follows:

$$
C=\frac{i_{o}}{4 \Delta V f_{P W M}}
$$

where il is the current across the inductor, $i_{c}$ is the current across the capacitor, vgis the input voltage, $v_{c}$ voltage across the capacitor, $i_{l}^{\bullet}=$ change in the current across the inductor, $v^{\bullet}{ }_{C}$ is the change in voltage across the capacitor during switching, fpwm is the switching frequency, $\Delta V$ is the output voltage ripple, $I_{0}$ is the output current, $\mathrm{D}$ is the duty cycle, $V_{0}$ is the output voltage. After calculation of the value of the inductor and capacitor we created Table 2, as below.

Table 2. Parameter of DC-DC boost converter.

\begin{tabular}{ccc}
\hline S.No & Name of the Parameter & Values \\
\hline 1 & $\mathrm{~V}_{\text {in }}$ & $12-22 \mathrm{~V}$ \\
2 & $\mathrm{~V}_{\text {out }}$ & $36 \mathrm{~V}$ \\
3 & $f_{P W M}$ & $20 \mathrm{KHz}$ \\
4 & $\mathrm{~L}_{\text {boost }}$ & $5 \mathrm{Mh}$ \\
5 & $\mathrm{C}_{\text {boost }}$ & $2200 \mu \mathrm{F}$ \\
6 & Diode & $5 \mathrm{~V}$ \\
7 & Relay & $40 \mathrm{~W}$ \\
8 & $\mathrm{P}_{\text {out }}$ & RHR30120 with $10 \mathrm{Amp}$ Heat Sink \\
9 & IGBT & KGT25 N120 N, 1200 V, 25 A, \\
& & Fast Recovery \\
\hline
\end{tabular}

\section{Modified Direct-Control Perturbation \& Observation Technique}

This technique is capable enough to track maximum power point (MPP) shown in Figure 9. The power level of the proposed technique was affected due to irradiance, unpredictable temperature and resistive (DC) load [26]. This method is very useful to obtain the MPP by the hill-climbing process. As per the literature, solar irradiance is directly proportional to power. If irradiance increases, power will be increased and vice versa. Table 3 represents the process of the implemented method [27]. The duty cycle plays a very vital role in deciding the perturbation. If the duty cycle is positive the change in power will be positive and the next perturbation will be positive. There are three more cases to discuss which are based on the duty cycle. If the change in power is negative (-ve) then the next perturbation will be negative that depends upon the nature of the duty cycle. In the next case, if the duty is negative and change in power is positive then the next perturbation would be negative. This process will be ongoing until it reaches the highest power [28].

Table 3. Description of the modified Direct-Control Perturbation \& Observation technique [9].

\begin{tabular}{ccc}
\hline Perturbation & Change in Power & Next Perturbation \\
\hline +ve & $+\mathrm{ve}$ & $+\mathrm{ve}$ \\
$+\mathrm{ve}$ & $-\mathrm{ve}$ & $-\mathrm{ve}$ \\
$-\mathrm{ve}$ & $+\mathrm{ve}$ & $-\mathrm{ve}$ \\
$-\mathrm{ve}$ & $-\mathrm{ve}$ & $+\mathrm{ve}$ \\
\hline
\end{tabular}

The flow chart of this method shows very few sensors are utilized which makes it very cheap. The operating voltage is sampled and the algorithm changes the operating voltage in the required direction of slop $\mathrm{dP} / d V$.

If $\mathrm{dP} / d V$ is positive, then the algorithm increases the voltage value towards the MPP until $\mathrm{dP} / d V$ is negative. This iteration is continued until the algorithm finally reaches the MPP. The voltage never actually reaches an exact value but perturbs around the MPP.

As soon as the slope becomes high the perturbation step will be more and vice versa. This calculation helps to improve the fast-tracking MPP. 
There is so much literature available on various MPPT methods but the reason to choose this MPPT is improvisation in the conventional P\&O by using direct controlling with the help of a proportional integral derivative (PID) controller. There are unique features associated with the proposed technique, which are also shown in Figure 8.

- Very less PV array dependency;

- It has the power to give true MPPT;

- To get analog and digital output;

- Having fast convergence speed;

- Low complexity;

- Having a fewer number of sensors.

\section{Arm Cortex Microcontroller}

There is a lack of literature for investigating the use of STMicroelectronics 32-bit arm as an MPPT controller with the specialty of an inexpensive, high performance, rapid processor, and easy to install feature which is supported by MATLAB 2014 and above versions. The microcontroller is a potential solution to the problem of low conversion efficiency in standalone solar systems. In this study, deploying MATLAB and STMicroelectronics-32-bit development board containing an ARM Cortex M4 microcontroller. For obtaining real-time operation on the PV system, the practical test is set up for easy and rapid changes with modified DC-P\&O algorithm, to find the real data to track MPP in a short duration for small-scale stand-alone solar energy systems. Rapid control added more advantages to its performance. Mathematical models of modified DC-P\&O are designed on MATLAB in Figure 9. The results were obtained under different irradiation and temperature levels with different modulation indexes. Designed Simulink models were transferred into the control board with the help of the Waijung block set on MATLAB [28,29].

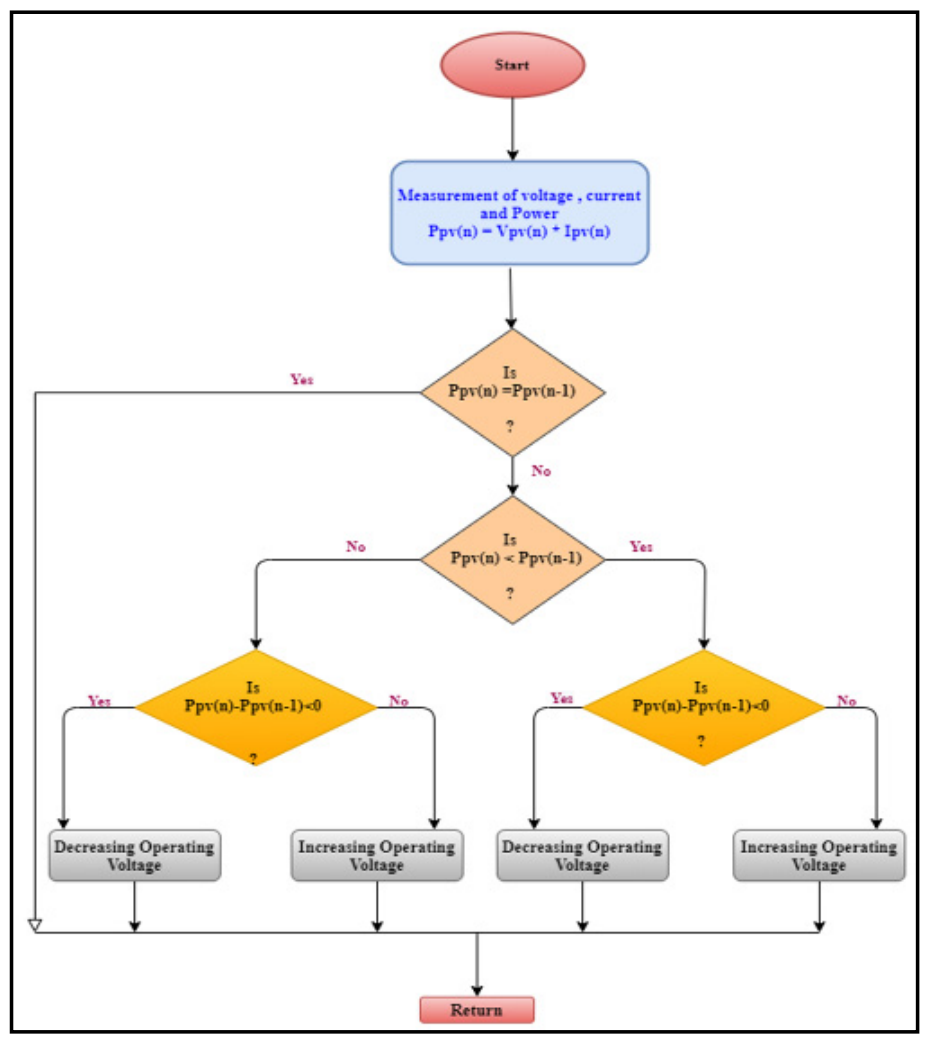

Figure 9. Modified direct control perturbation \& observation (DC-P\&O) technique. 


\section{Reasons to Choose}

- It has a $1 \mathrm{MB}$ flash memory, $192 \mathrm{~KB}$ RAM in LQFP100 package running at $168 \mathrm{MHz}$ providing a peak through $210 \mathrm{MIPs}$, comparatively greater than others (STM32 G491, STMG4 A1 with $512 \mathrm{~KB}$ of flash memory);

- It has an on-board ST-LINK/V2 debugger for the hardware;

- It has $3 \times 12$ bit, 2.4 MSPS A/D converter up to 24 channels, and $2 \times 12$ bit D/A converter;

- General-purpose 16-stream DMA Controller with FIFOs;

- There are 17 timers (12 for 16-bit and 2 for 32 bit with $168 \mathrm{MHz}$ ) present on the board;

- There are six PWM channels with programmable dead time insertion;

- The proposed hardware has 15 communication ports;

- The proposed microcontroller has up to $5 \mathrm{~V}$ tolerances, which are better than existing microcontrollers.

\section{Experimental Setup}

The experimental block diagram is shown in Figure 10 for testing the MPPT algorithm. The panel was illuminated with artificial light (halogen lamp); the intensity of artificial light was controlled by connecting the autotransformer and getting real data at different temperatures. The PV was connected to the DC-DC boost convertor as per the rating of the PV panel [30].

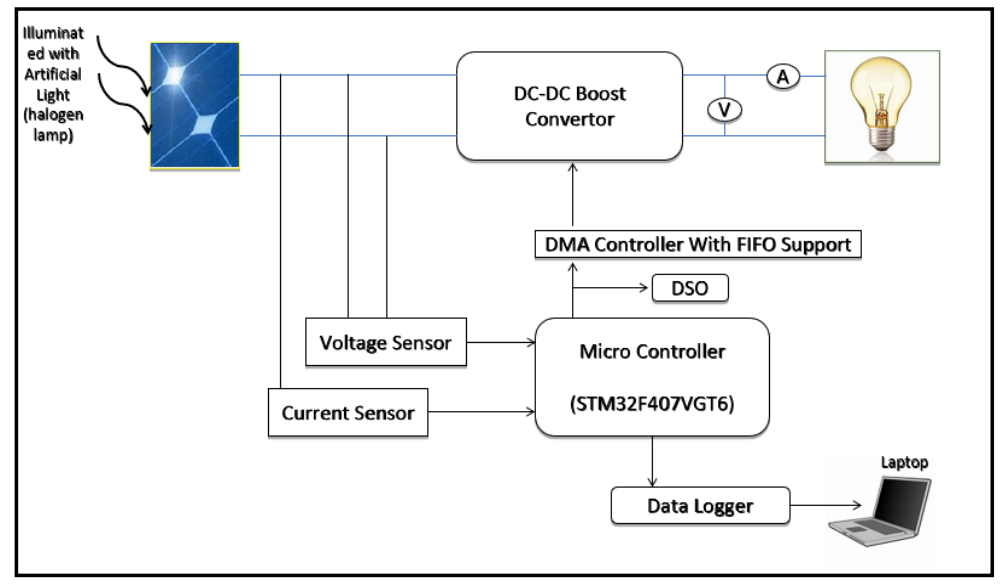

Figure 10. Block diagram of the experimental setup.

Input voltage and current are sensed by respective sensors and given input by the ARM Cortex M4 microcontroller (STM32 F407 VGT6). This ARM controller was used to simplify the process of the proposed MPPT and record the gate pulse through gate terminals or by sensing the output unit through a digital storage oscilloscope. A direct memory access (DMA) controller added more advantages with first in first out support (FIFO) for this user-friendly process with the help of PID. All data can be recorded with the help of a data logger, which is built-in programming [31,32]. The experimental set up is shown in Figure 11a,b. 


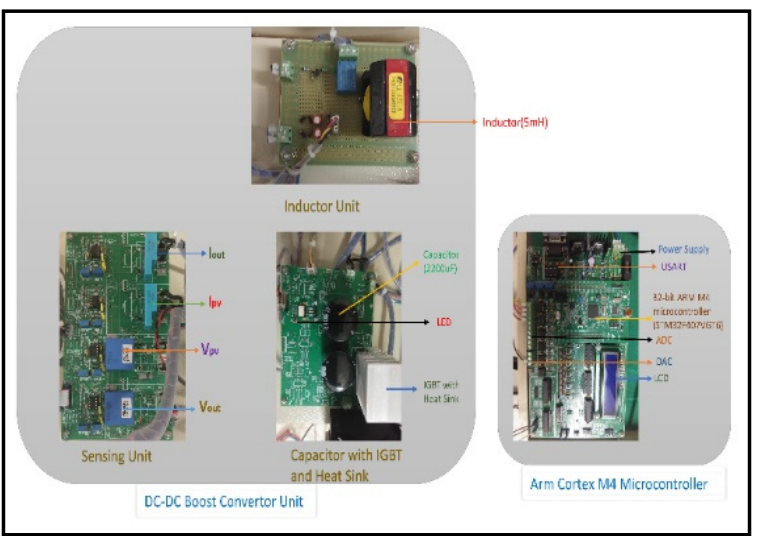

(a)

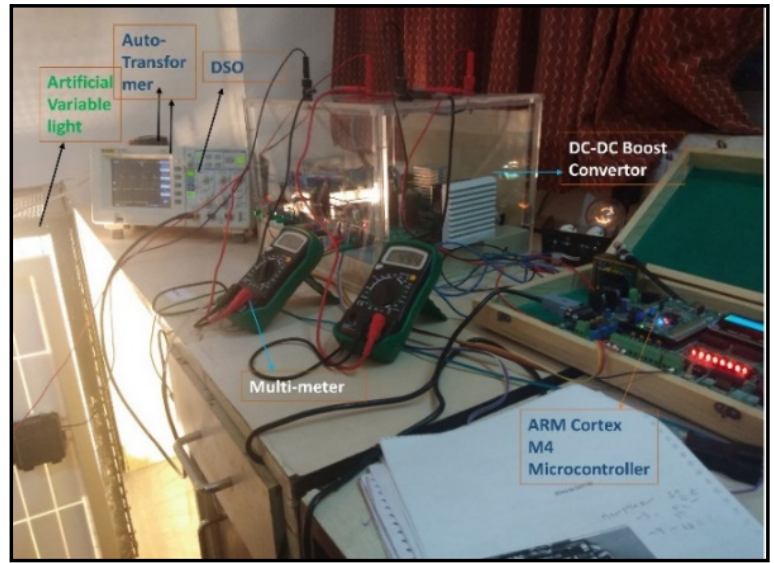

(b)

Figure 11. (a) Hardware components of experimental setup; (b): experimental set up.

\section{Results and Discussion}

The attainment of the objectives was to look for an efficient, user-friendly, and high performing MPPT system with rapid changes. It allows the uses of electricity in the standalone DC grid. The simulation was tested in the MATLAB to understand the nature of the algorithm and introduce a quick transition in the system implementation [33,34].

Figure 12 represents the model of experimental studies with the ARM cortex microcontroller for implementation of the modified (DC-P\&O) technique. This technique is quite useful and user-friendly with the ARM Cortex M4 microcontroller (STM32 F407 VGT6) for getting good results. This algorithm can reach the MPP within $0.11 \mathrm{sec}$ as shown in Figure $13[35,36]$.

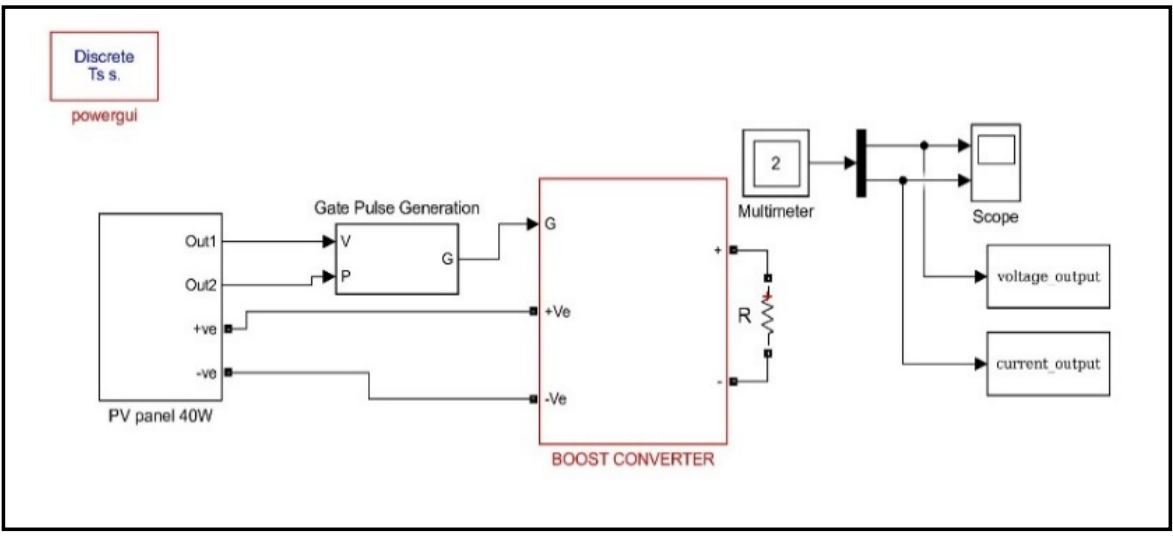

Figure 12. MATLAB Simulink model for hardware. 


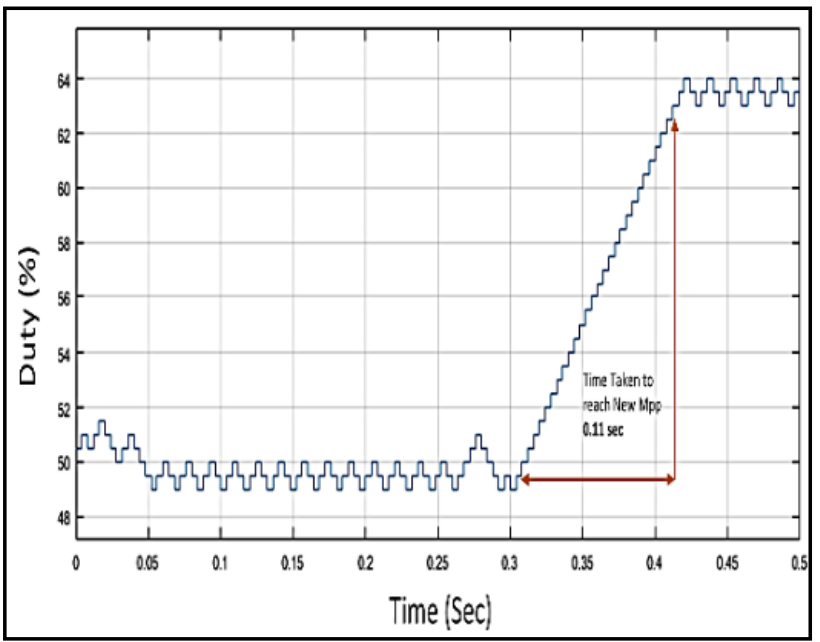

Figure 13. Duty vs. time.

The maximum output power was reached in a very short period of $0.02 \mathrm{~s}$ as shown in Figure 14. The proposed techniques help to reduce the steady-state oscillation and fast-tracking [37].

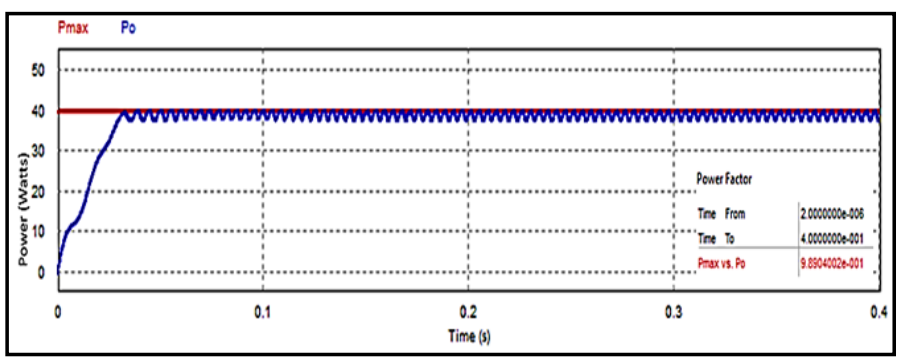

(a)

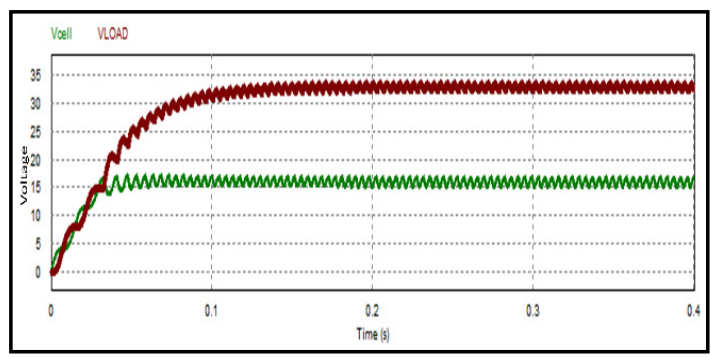

(b)

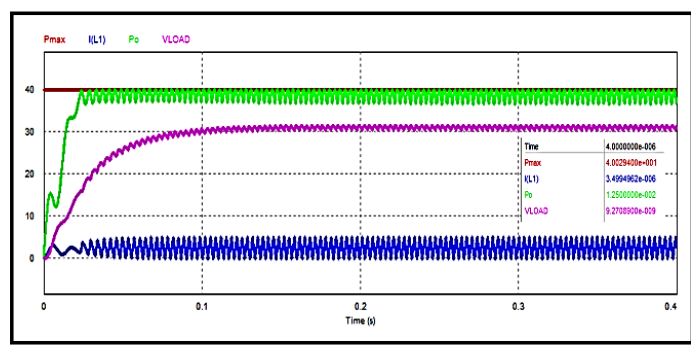

(c)

Figure 14. (a) Maximum power $V_{m p}$ vs. time; (b) output power Pout vs. time; (c) load voltage $V_{L}$ vs. time and load current $\mathrm{I}_{\mathrm{L}}$ vs. time. 
By varying the duty cycle of the boost converter (30\% 50\% 68\%) for open-loop and closed-loop control, the convertor gave good real-time results on these duties cycles as the algorithm suggested [38].

By comparing the output voltage and control pulse of the DC-DC boost converter by simulation and hardware results at (30\% 50\% 68\%), the duty cycle is shown in Figure 15.

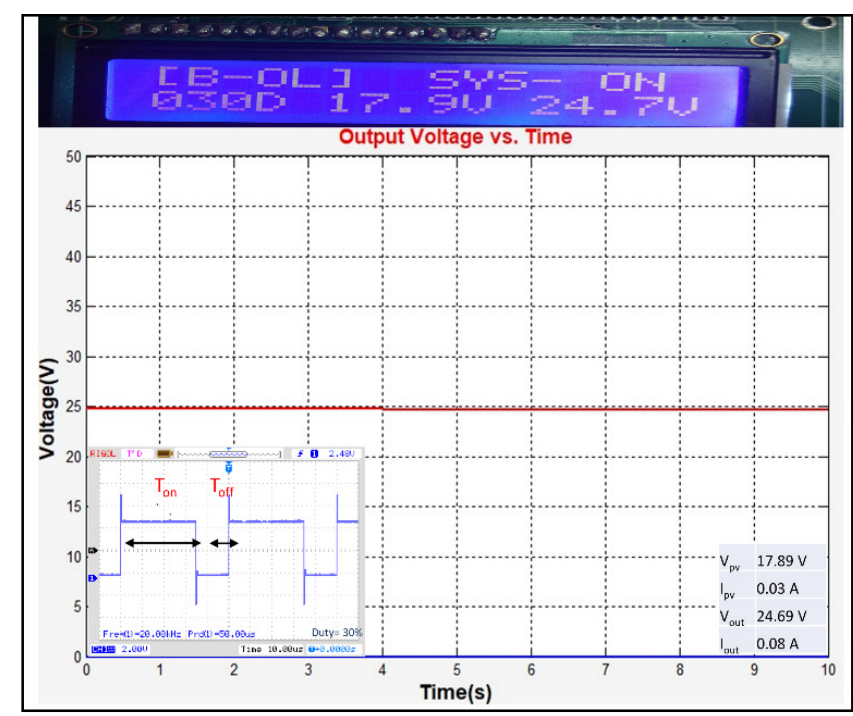

(a)

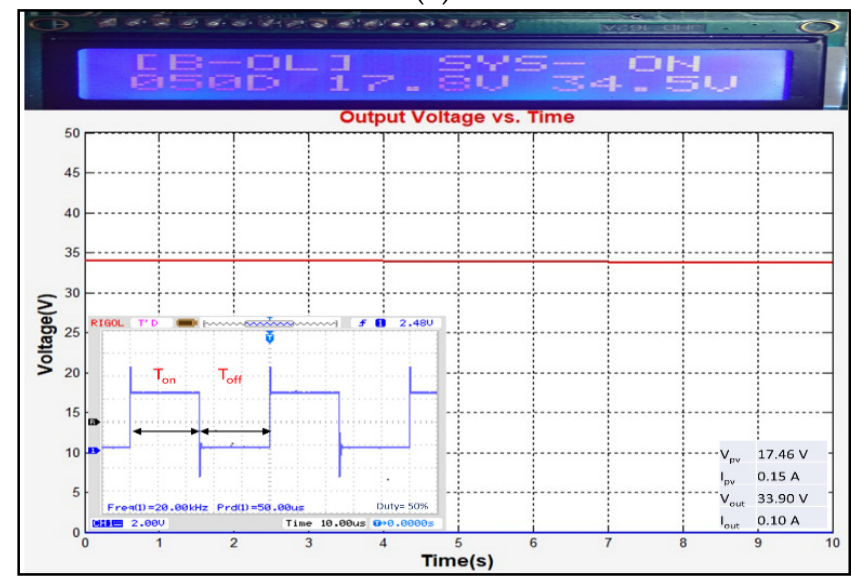

(b)

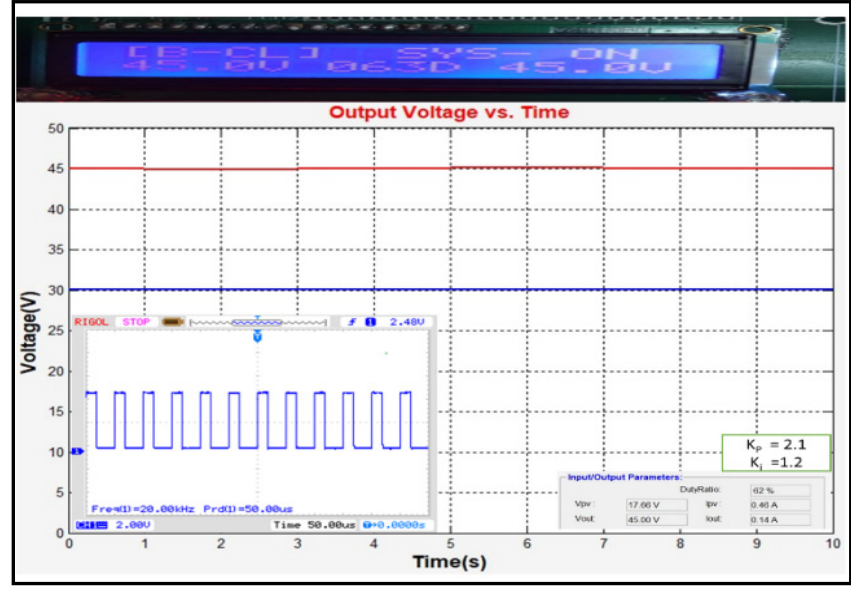

(c)

Figure 15. Results of DC-DC boost converter with the duty of (a) $30 \%$; (b) 50\%; and (c) $68 \%$ for open loop, respectively. 
In Figure 15, the open-loop control system of the boost convertor is shown for different duty cycles $(30 \% 50 \% 68 \%)$. It is observed that as soon as the duty cycle increased the output voltage increased and the input voltage slightly decreased by 10 micro sec.

Figure 16 shows the result of a boost converter in the closed-loop control with the duty cycle of $63 \%$ where $K_{p}$ and $K_{i}$ are 2.1 and 1.2, respectively. The PID controller was used to control the gate pulse [39]. The gate pulse operates at $20 \mathrm{kHz}$ in 50 micro sec for open loop and closed loop, respectively. In the real-time analysis, authors found that the boost convertor was more compatible with the ARM Cortex 32-bit microcontroller with the Waijung block [40].

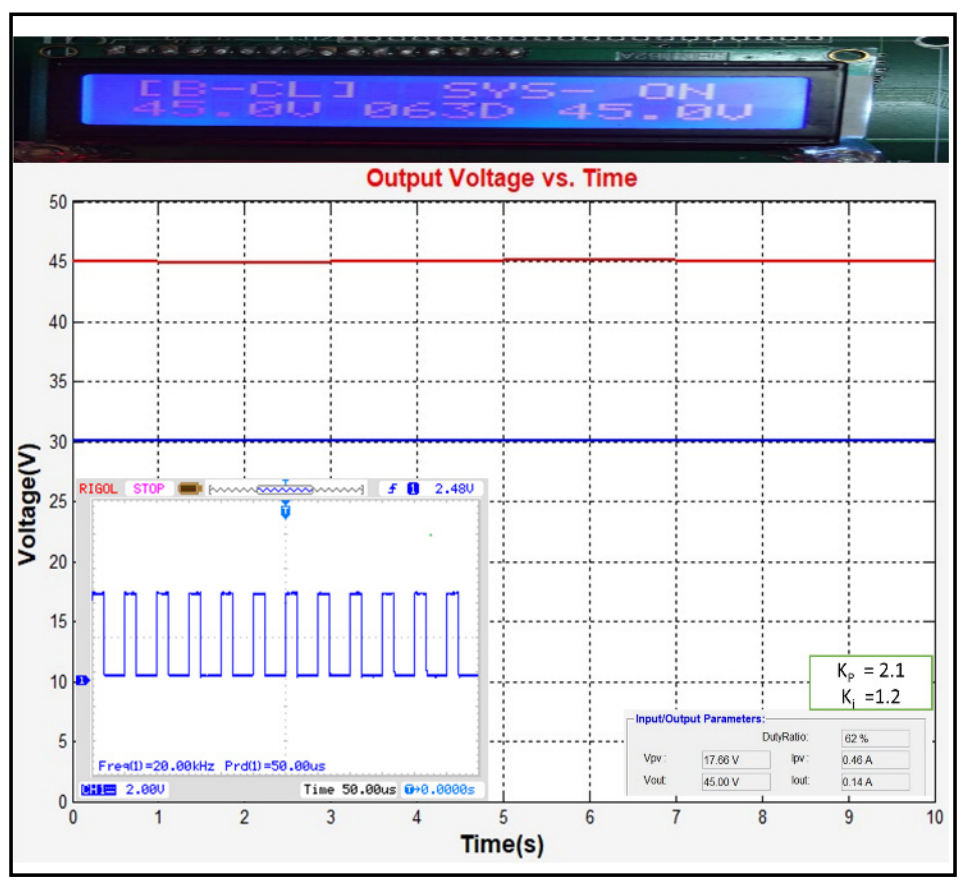

Figure 16. Results of boost convertor with the duty of $63 \%$ for the closed-loop system.

It is clearly shown that the closed-loop action performed very well for getting an output voltage of $45 \mathrm{~V}$ with the supportive action of a boost convertor.

Figure 17a,b represents PV and IV curves at insolation of $270 \mathrm{~W} / \mathrm{m}^{2}$ with real-time tracing of MPP by using the modified DC-P\&O method. It is helpful to fetch the real-time parameters easily with the help of Waijung.

Comparative studies of hardware and software results of DC P\&O technique at $270 \mathrm{~W} / \mathrm{M}^{2}$ are shown in Table 4. Due to hardware limitations the experiment was not performed, only a simulation study was conducted at $800 \mathrm{~W} / \mathrm{M}^{2}$. 


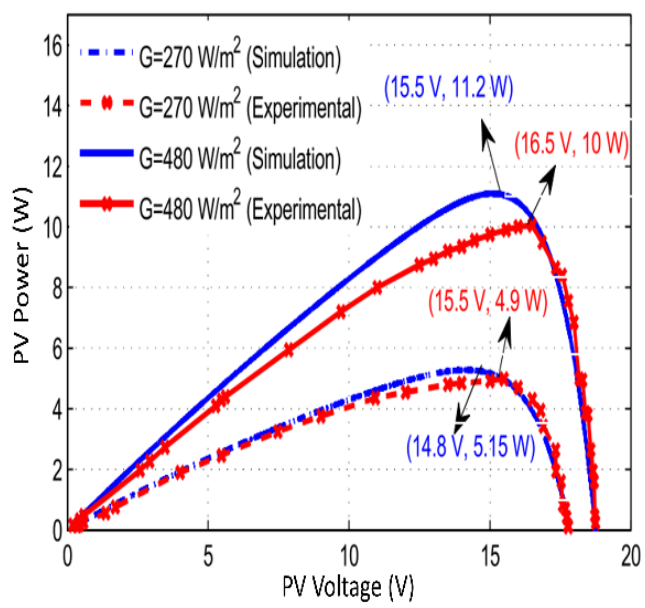

(a)

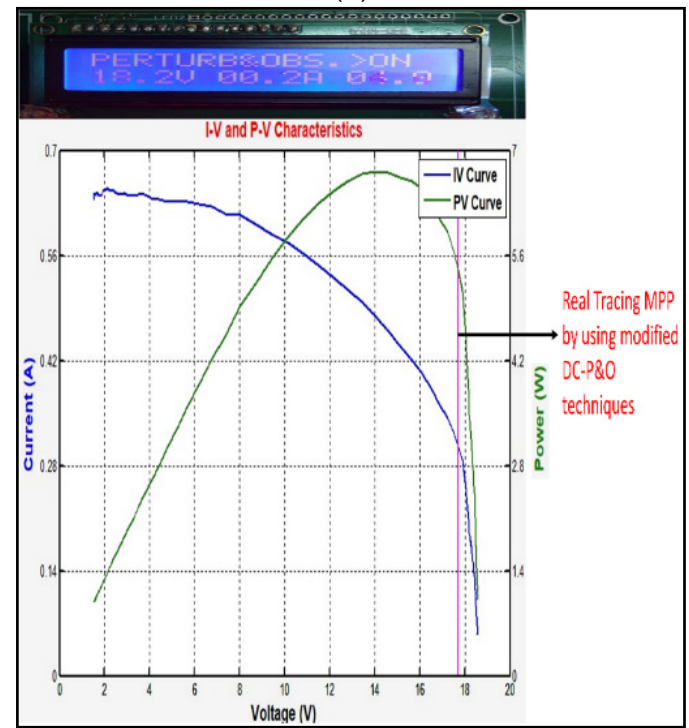

(b)

Figure 17. (a) Real-time PV curve; (b): real-time IV curve.

Table 4. Comparative results of simulation and hardware of DC-P\&O technique at $800 \mathrm{~W} / \mathrm{M}^{2}$, and $270 \mathrm{~W} / \mathrm{M}^{2}$

\begin{tabular}{|c|c|c|c|c|}
\hline S.NO & Parameter & $\begin{array}{c}\text { Simulation } \\
\text { Results at } 800 \\
\text { W/M }\end{array}$ & $\begin{array}{c}\text { Simulation } \\
\text { Results at } 270 \\
\text { W/M }\end{array}$ & $\begin{array}{c}\text { Hardware } \\
\text { Results at } 270 \\
\text { W/M }\end{array}$ \\
\hline 1 & Voc & $17.5 \mathrm{~V}$ & $18.50 \mathrm{~V}$ & $18.56 \mathrm{~V}$ \\
\hline 2. & Isc & $2.15 \mathrm{~A}$ & $0.6 \mathrm{~A}$ & $0.635 \mathrm{~A}$ \\
\hline 3. & $\mathrm{Vmp}$ & $17.5 \mathrm{~V}$ & $14.8 \mathrm{~V}$ & $15.5 \mathrm{~V}$ \\
\hline 4. & $\operatorname{Imp}$ & $1.75 \mathrm{~A}$ & $0.5 \mathrm{~A}$ & $0.48 \mathrm{~A}$ \\
\hline 5. & Duty Ratio & $57 \%$ & $57 \%$ & $57 \%$ \\
\hline 6. & Vout & $40.02 \mathrm{~V}$ & $39.4 \mathrm{~V}$ & $40.74 \mathrm{~V}$ \\
\hline 7. & MPP reaching Time & $0.11 \mathrm{~s}$ & $0.11 \mathrm{~s}$ & $0.68 \mathrm{~s}$ \\
\hline 8. & $\begin{array}{l}\text { Insolation with } \\
\text { Artificial Light }\end{array}$ & $800 \mathrm{~W} / \mathrm{M}^{2}$ & $270 \mathrm{~W} / \mathrm{M}^{2}$ & $270 \mathrm{~W} / \mathrm{m}^{2}$ \\
\hline 9. & Pout & $27.5 \mathrm{~W}$ & $5.15 \mathrm{~W}$ & $4.9 \mathrm{~W}$ \\
\hline 10. & Real-time Ppv & $33.2 \mathrm{~W}$ & $6 \mathrm{~W}$ & $5.8 \mathrm{~W}$ \\
\hline 11. & Conversion efficiency & $82.83 \%$ & $85.88 \%$ & $84.48 \%$ \\
\hline
\end{tabular}


It is essential to study the hardware results with the proposed technique from Table 5, where the open circuit voltage is $18.56 \mathrm{~V}$, short circuit current is $0.635 \mathrm{~A}$, maximum voltage is $15.5 \mathrm{~V}$, max current is $0.48 \mathrm{~A}$, and output power is $4.9 \mathrm{~W}$, which is $6.5 \%$ more than conventional $\mathrm{P} \& \mathrm{O}$ and conversion efficiency is more than $7.9 \%$.

Table 5. Compared hardware results of modified (DC-P\&O) technique with conventional P\&O.

\begin{tabular}{cccc}
\hline S.No & $\begin{array}{c}\text { Name of the } \\
\text { Parameter }\end{array}$ & Modified (DC-P\&O) & Conventional P\&O \\
1 & Voc & $18.56 \mathrm{~V}$ & $17.86 \mathrm{~V}$ \\
2 & Isc & $0.635 \mathrm{~A}$ & $1.59 \mathrm{~A}$ \\
3 & Vmp & $15.5 \mathrm{~V}$ & $12.93 \mathrm{~V}$ \\
4 & Imp & $0.48 \mathrm{~A}$ & $0.43 \mathrm{~A}$ \\
5 & Pmp & $6.7 \mathrm{~W}$ & $5.6 \mathrm{~W}$ \\
6 & Conversion efficiency & $84.48 \%$ & $76.56 \%$ \\
7 & Panel Efficiency & $13 \%$ & $12.2 \%$ \\
8 & Duty Ratio & $57 \%$ & $57 \%$ \\
9 & Real-time Vpv & $17.76 \mathrm{~V}$ & $15.46 \mathrm{~V}$ \\
10 & Real-time Ipv & $0.38 \mathrm{~V}$ & $1.23 \mathrm{~V}$ \\
11 & Real-time Ppv & $6.8 \mathrm{~W}$ & $5.6 \mathrm{~W}$ \\
12 & Vout & $40.74 \mathrm{~V}$ & $39.8 \mathrm{~V}$ \\
13 & Iout & $0.135 \mathrm{~A}$ & $0.12 \mathrm{~A}$ \\
\hline
\end{tabular}

\title{
8. Conclusions
}

The authors have analyzed the following:

- The modified DC-P\&O is having better results, i.e., output power is $4.9 \mathrm{~W}$ which is $6.5 \%$ more than convention $\mathrm{P} \& \mathrm{O}$ and conversion efficiency is more than $7.9 \%$ in comparison with conventional $\mathrm{P} \& \mathrm{O}$.

- $\quad$ The modified DC-P\&O helps the boost converter for improving fast-tracking MPP through PID.

- $\quad$ The proposed experiment can efficiently analyze the DC-DC boost converter operating in open-loop, closed-loop, real-time capturing and analyzing PV curve of MPPT.

- The conversion efficiency of PV panel was found to be $84.48 \%$ with the ARM microcontroller in comparison to $76.56 \%$ found from conventional P\&O.

- $\quad$ The proposed method is better suited to a stand-alone PV system because it requires a very low voltage (12-48 volts).

Author Contributions: Conceptualization, A.K.S. and N.S.B.; Methodology, K.A. and A.I.; Software, K.A., J.A.D., and A.M.; Validation, A.K.S., N.S.B. and P.K.C.; Formal analysis, A.M. and H.G.; Investigation, A.K.S., N.S.B. and K.A.; Resources, A.K.S. and K.A.; Data Curation, A.K.S. and J.A.D.; Writing—original draft preparation, V.K.S. and J.A.D.; Writing—review and editing, A.K.S., N.S.B., K.A. and J.A.D.; Visualization, A.M. and V.K.S.; Supervision, K.A., P.K.C. and H.G.; Project administration, A.K.S., N.S.B., K.A. and J.A.D. All authors have read and agreed to the published version of the manuscript.

Funding: This research received no external funding.

Institutional Review Board Statement: Not applicable.

Informed Consent Statement: Not applicable.

Data Availability Statement: Not applicable.

Conflicts of Interest: The authors declare no conflict of interest.

\author{
Abbreviation \\ Term \\ Description \\ MPPT \\ Maximum power point technique
}




$\begin{array}{ll}\text { DC-P\&O } & \text { Direct control- perturbation \& observe } \\ \text { RES } & \text { Renewable energy sources } \\ \text { P\&O } & \text { Perturbation \& observe } \\ \text { PSIM } & \text { Power simulator } \\ \text { FLC } & \text { Fuzzy logic control } \\ \text { GS } & \text { Green sources } \\ \text { PV } & \text { Photovoltaic Cell } \\ \text { MPP } & \text { Maximum power point } \\ \text { MOSFET } & \text { Metal-oxide field-effect transistor } \\ \text { IGBT } & \text { Insulated gate bipolar transistor } \\ \text { CCM } & \text { Continuous conduction mode } \\ \text { PWM } & \text { Pulse width modulation } \\ \text { DC } & \text { Direct current } \\ \text { PID } & \text { Proportional integral derivative } \\ \text { RAM } & \text { Random access memory } \\ \text { D/A } & \text { Digital to analog } \\ \text { DMA } & \text { Direct memory access } \\ \text { FIFO } & \text { First in first out } \\ \text { Voc } & \text { Open circuit voltage } \\ \text { Isc } & \text { Short circuit current } \\ \text { Vmp } & \text { Voltage at maximum power } \\ \text { Imp } & \text { Current at maximum power } \\ \text { Vout } & \text { Output voltage } \\ \text { Iout } & \text { Output current } \\ \text { Pout } & \text { Output power } \\ & \end{array}$

\section{References}

1. Salman, S.; Xin, A.I.; Zhouyang, W.U. Design of a P-\&-O algorithm based MPPT charge controller for a stand-alone 200W PV system. Prot. Control. Mod. Power Syst. 2018, 3, 1-8.

2. Ahmad, R.; Murtaza, A.F.; Sher, H.A. Power tracking techniques for efficient operation of photovoltaic array in solar applicationsA review. Renew. Sustain. Energy Rev. 2019, 101, 82-102. [CrossRef]

3. Ram, J.P.; Rajasekar, N. A novel flower pollination based global maximum power point method for solar maximum power point tracking. IEEE Trans. Power Electron. 2017, 32, 8486-8499.

4. Teng, J.H.; Huang, W.H.; Hsu, T.A.; Wang, C.Y. Novel and fast maximum power point tracking for photovoltaic generation. IEEE Trans. Ind. Electron. 2016, 63, 4955-4966. [CrossRef]

5. Seyedmahmoudian, M.; Horan, B.; Soon, T.K.; Rahmani, R.; Oo, A.M.; Mekhilef, S.; Stojcevski, A. State of the art artificial intelligence-based MPPT techniques for mitigating partial shading effects on PV systems-A review. Renew. Sustain. Energy Rev. 2016, 64, 435-455. [CrossRef]

6. Singh, O.; Gupta, S.K. A review on recent Mppt techniques for photovoltaic system. In Proceedings of the 2018 IEEMA Engineer Infinite Conference (eTechNxT), New Delhi, India, 13-14 March 2018; pp. 1-6.

7. Dallago, E.; Liberale, A.; Miotti, D.; Venchi, G. Direct MPPT algorithm for PV sources with only voltage meas-urements. IEEE Trans. Power Electron. 2015, 30, 6742-6750. [CrossRef]

8. Paz, F.; Ordonez, M. Zero oscillation and irradiance slope tracking for photovoltaic MPPT. IEEE Trans. Ind. Electron. 2014, 61, 6138-6147. [CrossRef]

9. Rezk, H.; Eltamaly, A.M. A comprehensive comparison of different MPPT techniques for photovoltaic systems. Sol. Energy 2015, 112, 1-11. [CrossRef]

10. Dengsheng, W.; Lidi, W.; Chuncheng, H.; Tong, L.; Chenglong, Z.; Chenyang, L. Research and Design of PV MPPT Based on STM32. In Proceedings of the 2018 Chinese Control and Decision Conference (CCDC), Shenyang, China, 9-11 June 2018; pp. 4971-4974.

11. Ba, A.; Ehssein, C.O.; Mahmoud, M.E.; Hamdoun, O.; Elhassen, A. Comparative study of different DC/DC power converter for optimal PV system using MPPT (P\&O) method. Appl. Sol. Energy 2018, 54, 235-245.

12. Valenciaga, F.; Inthamoussou, F.A. A novel PV-MPPT method based on a second-order sliding mode gradient observer. Energy Convers. Manag. 2018, 176, 422-430. [CrossRef]

13. Rekioua, D. MPPT methods in hybrid renewable energy systems. In Hybrid Renewable Energy Systems; Springer: Cham, Switzerland, 2020; pp. 79-138.

14. National Institute of Solar Energy. Available online: https://www.mnre.gov.in (accessed on 18 August 2021).

15. PV Performance Modeling Collaborative National Technology and Engineering Solutions of Sandia. Available online: https: //pvpmc.sandia.gov/modeling-steps/2-dc-module-iv/diode-equivalent-circuit-models/ (accessed on 22 August 2021). 
16. Shang, L.; Guo, H.; Zhu, W. An improved MPPT control strategy based on incremental conductance algorithm. Prot. Control Mod. Power Syst. 2020, 5, 1-8. [CrossRef]

17. Salman, S.; Xin, A.; Masood, A.; Jan, M.U.; Iqbal, S. Impact of DC-DC Converters for DC Grid Voltage Support. In Proceedings of the 2019 IEEE 3rd Conference on Energy Internet and Energy System Integration (EI2), Changsha, China, 8-10 November 2019; pp. 1949-1953.

18. Mahmood, M.H.; Ali, I.I.; Ahmed, O.A. Design and Implementation of Intelligent MPPT Based on FPGA for PV System. In IOP Conference Series: Materials Science and Engineering; IOP Publishing: Philadelphia, PA, USA, 2020; Volume 881, p. 012138.

19. Kulaksiz, A.A.; Alhajomar, F.; Gokkus, G. Rapid Control Prototyping based on 32-Bit ARM Cortex-M3 Microcontroller for Photovoltaic MPPT Algorithms. Int. J. Renew. Energy Res. (IJRER) 2019, 9, 1938-1947.

20. Kabalci, E. Maximum power point tracking (MPPT) algorithms for photovoltaic systems. In Energy Harvesting and Energy Efficiency; Springer: Cham, Switzerland, 2017; pp. 205-234.

21. Li, S. A variable-weather-parameter MPPT control strategy based on MPPT constraint conditions of PV system with inverter. Energy Convers. Manag. 2019, 197, 111873. [CrossRef]

22. Necaibia, S.; Kelaiaia, M.S.; Labar, H.; Necaibia, A. Implementation of an improved incremental conductance MPPT control based boost converter in photovoltaic applications. Int. J. Emerg. Electr. Power Syst. 2017, 18, 1-19. [CrossRef]

23. Elyaqouti, M.; Hakim, S.; Farhat, S.; Bouhouch, L.; Ihlal, A. Implementation in Arduino of MPPT using variable step size P\&O algorithm in PV installations. Int. J. Power Electron. Drive Syst. 2017, 8, 434.

24. Hashim, N.; Salam, Z.; Johari, D.; Ismail, N.F.N. DC-DC boost converter design for fast and accurate MPPT algorithms in stand-alone photovoltaic system. Int. J. Power Electron. Drive Syst. 2018, 9, 1038. [CrossRef]

25. Dhaouadi, G.U.I.Z.A.; Djamel, O.U.N.N.A.S.; Youcef, S.O.U.F.I.; Salah, C. Implementation of incremental conductance based MPPT algorithm for photovoltaic system. In Proceedings of the 2019 4th International Conference on Power Electronics and their Applications (ICPEA), Elazig, Turkey, 25-27 September 2019; pp. 1-5.

26. Abdel-Salam, M.; El-Mohandes, M.T.; El-Ghazaly, M. An efficient tracking of MPP in PV systems using a newly-formulated P\&O-MPPT method under varying irradiation levels. J. Electr. Eng. Technol. 2020, 15, 501-513.

27. Abdel-Salam, M.; Mohamed-Tharwat, E.M.; Goda, M. On the Improvements of Perturb-and-Observe-Based MPPT in PV Systems. In Modern Maximum Power Point Tracking Techniques for Photovoltaic Energy Systems; Springer: Cham, Switzerland, 2020; pp. 165-198.

28. Kenan, Ö.Z.E.L.; Karaarslan, A. The design of standalone pv system using p\&o algorithm for maximum power point tracking. Commun. Fac. Sci. Univ. Ank. Ser. A2-A3 Phys. Sci. Eng. 2020, 62, 14-25.

29. Haque, A. Maximum power point tracking (MPPT) scheme for solar photovoltaic system. Energy Technol. Policy 2014, 1, 115-122. [CrossRef]

30. Haque, A. A fast and reliable perturb and observe maximum power point tracker for solar PV system. Int. J. Syst. Assur. Eng. Manag. 2017, 8, 773-787. [CrossRef]

31. Jotham Jeremy, L.; Ooi, C.A.; Teh, J. Non-isolated conventional DC-DC converter comparison for a photovoltaic system: A review. J. Renew. Sustain. Energy 2020, 12, 013502. [CrossRef]

32. Babu, S.S.; Chary, S.S.K.; Abdullah, S.M.; Elangovan, D.; Karuppa, R.R.T. Design and analysis of power convertors for electric vehicle applications. In IOP Conference Series: Earth and Environmental Science; IOP Publishing: Philadelphia, PA, USA, 2019; Volume 312, p. 012026.

33. Ram, J.P.; Babu, T.S.; Rajasekar, N. A comprehensive review on solar PV maximum power point tracking techniques. Renew. Sustain. Energy Rev. 2017, 67, 826-847. [CrossRef]

34. Chaibi, Y.; Salhi, M.; El-Jouni, A. Sliding mode controllers for standalone PV systems: Modeling and approach of control. Int. J. Photoenergy 2019, 2019, 5092078. [CrossRef]

35. Rezaei, M.M.; Asadi, H. A modified perturb-and-observe-based maximum power point tracking technique for photovoltaic energy conversion systems. J. Control Autom. Electr. Syst. 2019, 30, 822-831. [CrossRef]

36. Schuss, C.; Fabritius, T.; Eichberger, B.; Rahkonen, T. Moving photovoltaic installations: Impacts of the sampling rate on maximum power point tracking algorithms. IEEE Trans. Instrum. Meas. 2019, 68, 1485-1493. [CrossRef]

37. Necaibia, S.; Kelaiaia, M.S.; Labar, H.; Necaibia, A.; Logerais, P.O. Boost Chopper Implementation based on Variable MPPT Duty Cycle Control Applied to Photovoltaic Systems. In Proceedings of the 2017 International Renewable and Sustainable Energy Conference (IRSEC), Tangier, Morocco, 4-7 December 2017; pp. 1-6.

38. Singhal, A.K.; Narvey, R.; Gwalior, S. PSIM and MATLAB based Simulation of PV Array for Enhance the Performance by using MPPT Algorithm. Int. J. Electr. Eng. (IEEE) 2011, 4, 511-520.

39. Jana, S.; Kumar, N.; Mishra, R.; Sen, D.; Saha, T.K. Development and implementation of modified MPPT algorithm for boost converter-based PV system under input and load deviation. Int. Trans. Electr. Energy Syst. 2020, 30, e12190. [CrossRef]

40. Bayrak, G.; Ghaderi, D. An improved step-up converter with a developed real-time fuzzy-based MPPT controller for PV-based residential applications. Int. Trans. Electr. Energy Syst. 2019, 29, e12140. [CrossRef] 